\title{
THE HOMECOMING EXPERIENCE: THE ENEMY NEVER DIES
}

Fabrício Paiva Araújo*

ABSTRACT: This article focuses on how the Vietnam post-war period affected the veterans in the United States, collaborating to understand how the representations of the vets' new identity was shaped as being the consequence of the traumatic war experiences they suffered. The difficulties the veterans had to reintegrate into society begin in the U.S. airports as soon as they step on American soil. The way vets are portrayed in the aftermath of the war is the main purpose of the investigation here presented. Larry Heinemann's Paco Story and Ron Kovic'sBorn on the Fourth of July are the main war narratives used to support this investigation. The literary characters Kovic and Paco play importan roles in representing the vets' identity transformation process. This change passes through the investigation of new places of threat, enmity and conflicts that were gradually revealed in the ex-combatants' lives during the homecoming period.

KEYWORDS: Vietnam veteran, Post-war, War experience War literature
* fabriciopaiva@yahoo.com.br

Mestre em Literaturas de Expressão Inglesa pelo Programa de Pós-Graduação em Letras: Estudos Literários (UFMG). Membro do Núcleo de Estudos de
Guerra e Literatura (NEGUE), da UFMG.

RESUMO: O foco desse artigo está em como o período pósguerra do Vietnã afetou os veteranos nos Estados Unidos colaborando para entender como a representação da nova identidade destes militares reformados foi moldada pelas consequências das experiências traumáticas que eles sofreram. As dificuldades que os veteranos tiveram para se reintegrar na sociedade comecam nos aeroportos dos E.U.A. assim que eles pisam em solo americano. A forma como eles são representados no período subsequente a guerra é o propósito principal da investigação aqui apresentada. As narrativas de guerra essenciais usadas para ilustrar esta investigação são Paco Story, de Larry Heinemann, e Born on the Fourth of July, de Ron Kovic. Os personagens literários Kovic e Paco atuam em papéis importantes que representam o processo de transformação da identidade dos veteranos. Essa mudança passa pela investigação de novos lugares de ameaça, inimizades e conflitos que foram gradativamente revelados na vida dos ex-combatentes durante o período de retorno ao lar.

PALAVRAS-CHAVE: Veterano do Vietnã; Pós-guerra, Experiência de guerra, Literatura de guerra 
1. EASTLAKE. The Bamboo Bed, p. 139.
All the wrong people remember Vietnam. I think all the people who remember it should forget it, and all the people who forgot it should remember it.

Michael Herr, Dispatches.

For many American soldiers who fought the Vietnam War, coming back home was one of the most terrifying war experiences, not because the vets feared a turnaround of their official enemy, the Vietcongs, neither were they worried about being asked to go back to serve the U.S one more tour of duty in Vietnam, because many were the soldiers who went back to Vietnam for one more year of heavy army duties. On the contrary, the post-war was hard because many of the terrifying experiences undergone by American soldiers in the battlefield of Vietnam jungles drastically increased in their homeland. For the first time the so called 'biggest nation in the world' lost a war, and back in the United States the American veterans were forced to face prejudice and rejection from their own people. The vets were morally denied by Americans, and they often had their veteran rights refused.

The Vietnam War veterans were the generation of combatants that the American people tried hard to cross out of their memory. They were not a "lost generation" as William Eastlake explains, the Vietnam veterans were the "ignored generation, the generation that was used by old people to kill young people". ${ }^{1}$ The vets realized that even back home, where they were supposed to find a safe shelter, the war was not over, and "the tragedy of Vietnam War," as Arthur Neil pointed out, "continued for years after the war was over". ${ }^{2}$ The war fought back home increased day after day because of civilians' negative attitudes towards the veterans. Therefore, the Vietnam veterans had to find a new strategy to survive. They often felt confronted by their communities and their own people turned out to be their new 'enemies' Coming back home was the beginning of a new moment in the vets' lives and this hard process of returning home was faced, under great difficulty, at the very moment the vets stepped on the American soil.

This article focuses on the post-war period and especially on how the representations of the vets' new identity asserted in this period was shaped as being the consequence of the traumatic war experiences they suffered. The literary characters Kovic and Paco play important roles in illustrating the vets' identity transformation process, which passed through the investigation of new places of threat, enmity and conflicts that were gradually revealed in the veterans' lives during the homecoming period.

Many accounts have shown that it was in the American airports that face to face threats towards veterans started. The Americans airports became places where the vets' confusion in returning home began to mix with pain, isolation, and rejection. According to Paul Lyons,
2. NEIL. National Trauma and Collective Memory: extraordinary events in the American experience, p. 100
EM TESE
N. 2

MAIO-AGO. 2014 
3. A soldier in the U.S. armed forces. 1930s (originally denoting equipment supplied government (or general) issue.

government (or general) issue.

4. LYONS.Peace \& Change, p. 193.

5. APPY. Working-class war: American combat soldiers and Vietnam, p. 304. in the popular mythology about the return home of the Vietnam veteran there is always an ugly incident at the airport. The G.I. ${ }^{3}$ is confronted by angry, self-righteous protesters, usually described as long-haired and scruffy. The male hippies often seem to be performing before their girlfriends; the females seem to take great pleasure in throwing the epithet "baby-killers" in the vet's face. ${ }^{4}$

The Vietnam veterans were often met at the airports by protestors who were ready to show their hostile reception The vets were treated poorly and some of them reported being spat on, usually by the Americans hippies who saw the vets as losers. In his Working-Class War-American Combat Soldier and Vietnam, Christian Appy reports a veteran's experience:

I arrived at Los Angeles International Airport. ... On my way to the taxis, I passed two young women in the waiting area. One of these young women approached me and, in a low voice, called me a 'baby killer' and spat on my ribbons. I was in uniform and wearing the Vietnamese Service Medal, the Vietnamese Campaign Medal, an air Force Commendation Medal, and the Purple Heart. ${ }^{5}$

Therefore, being treated as criminals or murders at the American airports revealed that civilians strongly disapproved the return of Vietnam veterans and their war. This typical act of receiving the veterans badly became part of the substance of the stories that surround this particular postwar experience. The America the veterans returned to was completely different from the America they left before going to Vietnam. As Lyons has noted, in his survey made among the Vietnam Veterans of America (VVA), "most vets feel that American people made them feel 'invisible and ignored'; very few felt much appreciated and supported," other vets "felt that they were 'treated with hostility and anger,' one of whom recalls being 'jeered and cursed"' 6 Thus, if a vet did not experience protestors at airports, then the homecoming story is more limited to how they were treated among their relatives, friends, and strangers. Most civilians were totally apathetic on matters related to Vietnam. Harvard Sitikoff, a professor of history at the University of New Hampshire, explains that "the majority of Americans, it appeared, neither wanted to talk or think about their nation's longest and most debilitating war--the only war the United States ever lost". 7 Americans seemed not to care about the war anymore and many of them were trying to forget the war. The vets found themselves helpless and without any one to share their traumatic experiences. They returned home and tended to be alone, keeping their thoughts to themselves. They avoided talking about the war and being in touch with other veterans, who were, after all, behaving in a similar way, staying uncomfortably quiet to keep the
7. CHAMBERS II.The Oxford Companion to American Military History, p. 766. 
8. APPY. Working-class war: American combat soldiers and Vietnam, p. 3. secret about their heinous crime. Appy explains that the veterans "returned from Vietnam in virtual isolation, received no national homecoming ceremonies, and lacked adequate medical and psychological care, educational benefit, and job training". ${ }^{8}$ The vets were contaminated and alienated by the Vietnam War and often seen as strangers, aliens, indigenous or someone who has never belonged to America. They were the unwanted Americans, wronged and helpless.

On the other hand, the vets complained about the importance of letting America understand that they were not the only ones who lost the war. For them, the American nation lost it, and it is the nation's responsibility as a whole to admit American's first defeat. However, the vets soon realized that no one else would carry this shameful burden with them. The veterans felt alone, not safe, not confident, but completely insecure. The U.S. government, their friends and family had abandoned them. The vets were lonely and unhappy. They were forced to accept the difficulties and the unpleasant task of carrying this historical shame forever. They were blamed and judged by other Americans, who just like them were raised to believe that winning wars was something one took for granted in the United States. Batcheck, a chopper pilot, explains for two soldiers the reason for the American disapproval towards them: "It's because nobody in the States gives a damn about the Vietnam War. They want to forget it. Anyway, you're supposed to win a war. You remind them that it's still going on.
You're supposed to win a war or get killed. You guys didn't do either". ${ }^{9}$ The vets were devastated. They were digging in their hearts and minds new trenches to hide from their fellow countrymen the shame of an entire nation. Ashamed and confused, they could no longer live in peace with civilians and the U.S. government. Thus, many active political groups were created to support the veterans' cause against the war and these groups deliberately protested against the rejection and prejudice the veterans were going through. The vets wanted to be listened to and understood by America.

In her essay "Confronting Political Trauma," Cathy Caruth discusses the United States withdrawal from Vietnam and points out the vets' demand for such active political groups. According to Caruth,

this was perhaps the first war in the United States history in which the veterans of the war demanded-through active political groups such as Vietnam Vets Against the War, among others-that the citizens of our country, as well as the politicians in our government, listen to the experiences of soldiers at war and begin to see the war from the soldiers' own unique perspective. $^{10}$

The American soldiers who fought the Vietnam War arrived home not as heroes, but as "losers." Before trying to live a normal life in the U.S. and going out to protest against
9. EASTLAKE. The Bamboo Bed, p. 155.

10. CARUTH. Confronting Political Trauma, p. 179.
EM TESE

BELO HORIZONTE

v. 20

N. 2

MAIO-AGO. 2014

ARAÚJO. The homecoming experience: the enemy never dies

P. 208-229 
the American reaction to them, many of the defeated and unsuccessful veterans needed to pass through the sore tria and tribulation offered in the poor, rat-infested, and badly equipped military hospitals. Kovic remembers that just before his treatment in the VA hospitals he began to question the righteousness of war and the reasons people were protesting against the veterans. But after a while he started to realize that the beliefs he was holding for so long could be definitely wrong. As Kovic states:

I was in Vietnam when I first heard about the thousands of people protesting against the war in the streets of America. I didn't want to believe it at first - people protesting against us when we were putting our lives on the line for our country. The men in my outfit used to talk about it a lot. How could they do this to us? Many of us would not be coming back and many others would be wounded or maimed. We swore they would pay, the hippies and draft card burners. They would pay if we ever ran into them.

But the hospital had changed all of that. It was the end of whatever belief I'd still had in what I'd done in Vietnam. Now wanted to know what I had lost my legs for, why I and the others had gone at all. But it was still very hard for me to think of speaking out against the war, to think of joining those I'd once called traitors.
Kovic was devastated when he truly realized the impact of the Vietnam War in his country and on his own body. Kovic was not only physically injured, but also mentally damaged and traumatized for the rest of his life. In addition, the VA hospitals became for Kovic and many other veterans part of their war experiences. It was for many of them a humiliating and suffocating routine, and to get rid of it was often seen as an impossible mission. Kovic explains that when he arrived in America he was taken to one of these horrible hospitals with fifty other soldiers who were recently wounded in the war. He describes these soldiers as the following:

Twenty-year-old blind men and amputees, men without intestines, men who limped, men who were in wheelchairs and men in pain. He noticed they all had strange smiles on their faces and he had one too, he thought. They were men who had played with death and cheated it at a very young age. ${ }^{12}$

Kovic explains that the VA hospitals are as horrible as a "concentration camp," full of "broken" and "depressive" people, a place where it is possible to smell the "living death," and as Kovic succinctly puts it, "this is a nightmare". ${ }^{13}$ Nevertheless, the VA hospitals were also part of Paco's routine, and in one of these hospitals Paco was asked where he was from, but somehow he could not mention his hometown. He only remembered the war which was alive and still going on in his mind.
12. KOVIC. Born on the Fourth of July, p. 29.

13. KOVIC. Born on the Fourth of July, p. 35. 
14. HEINEMANN. Paco's Story, p. 152.

15. HEINEMANN. Paco's Story, p. 49

16. HEINEMANN. Paco's Story, p. 72

17. APPY. Working-class war: American combat soldiers and Vietnam, p. 13.
"From?" Paco repeats. "Not around here. Wounded in the war," Paco says, expecting an argument. "Got fucked up at a place called Fire Based Harriette near Phuc Luc," and he stretches his arm and turns his head to the side to show off his scars. "Been in the hospital.Got out of the Army.Convalesced in one VA hospital after another. Cane's to help with the

walking". ${ }^{14}$

The veteran Paco, "famous as the nameless wounded man from Alpha Company's massacre" ${ }^{15}$ had no home when he got back to the U.S. and no family or friends to welcome him back. He was alone and held by his vivid war memories, speculating his origin and the bad treatment he received in the VA hospitals, wondering whether he would find a place to sleep and work. As usual for Vietnam veterans, Paco was just trying to survive, "looking for anything steady", ${ }^{16}$ and wondering just as Kovic, how to get rid of the unwanted memories of war. Some of these memories keep reminding them of their treatment in the "decrepit, rat-infested VA hospital" ${ }^{17}$ Kovic however reinforces Appy's statement and writes about the dirty and declined VA hospitals where he received his treatment. As Kovic complains:

The men in my room throw their breadcrumbs under the radiator to keep the rats from chewing on our numb legs during the nights. We tuck our bodies in with the sheets wrapped around us. There are never enough aides to go around on the wards, and constantly there is complaining by the men. The most severely injured are totally dependent on the aides to turn them. They suffer the most and break down with sores. These are the voices that can be heard screaming in the night for help that never comes. Urine bags are constantly overflowing onto the floors while the aides play poker on the toilet bowls in the enema room. The sheets are never changed enough and many of the men stink from not being properly bathed. It never makes any sense to us how the government can keep asking money for weapons and leave us lying in our own filth. ${ }^{18}$

The military hospitals were unfortunate places where many vets had to start life again after the war was over. The vets were physically injured and often without anyone from their families or even a close friend to support them during their treatment, and because of their loneliness and lack of money there were no other treatment options affordable and available to them. The VA Hospitals remained as the vets only hope to be treated. Lonely and frightened to talk about the war, the vets often found themselves in a completely different world, in which American people were unable to help or simply comprehend the situation the vets were in. In Kovic's opinion "the hospital is like the whole war all over again". ${ }^{1}$ The hospitals were places that forced
18. KOVIC. Born on the Fourth of July, p. 39. 
20. KOVIC. Born on the Fourth of July, p. 37.

21. KOVIC. Born on the Fourth of July, p. 38. the veterans to hide their frustrations from their families and friends because they knew deep in their hearts that, in general, civilians would heavily criticize the situation they were in, blaming them for being responsible for their own misfortune. The vets suspected anyone, who after all could be a threat to increase the psychological and physical conflict they were passing through. Kovic, for instance, asserts that, "no one wants too many people to know how much of him has really died in the war". ${ }^{20}$ The conditions the vets went through in the VA hospitals humiliated them. They frequently felt ashamed, confused and disrespected. They were often treated in a stupid and unfair way by nurses and doctors who saw the vets as "something" that were part of their daily work. Thus, the vets lost respect of those who surrounded them. Explicating his frustration, Kovic complains about his sorrow and pain:

There is no real healing left anymore, everything that is going to heal has healed already and now I am left with the corpse the living dead man, the man with the numb legs, the man in the wheelchair, the Easter Seal boy, the cripple, the sexlessman, the man with the numb dick, the man who can't make children, the man who can't stand, the man who can't walk, the angry lonely man, the bitter man with the nightmares, the murder man, the man who cries in the shower. ${ }^{21}$
Nevertheless, for Kovic, Paco and other veterans there were no excuses for their pain and frustrations. They lost the war and had to learn how to deal with it. They were on the losers' side and had to understand as fast as they could how to behave properly to survive among so many Americans who acted as if they constantly wanted to blame the veterans "with hostility or as outright traitors". ${ }^{22}$ Therefore, in the veterans' lives the war traumas constantly increased and generated disequilibrium in human affairs, especially among the veterans who were now protesting against the war and against the civilians who thought the veterans had no plausible explanation to protests against the U.S. government. Kovic, however, states his reasons for trying to overcome the drama he was living.

I'm a Vietnam Veteran. I gave America my all and the leaders of this government threw me and the others way to rot in their V.A. hospitals. What's happening in Vietnam is a crime against humanity, and I just want the American people to know that we have come all the way across this country, sleeping on the ground and in the rain, to let the American people see for themselves the men who fought their war and have come to oppose it. If you can't believe the veteran who fought the war and was wounded in the war, who can believe. ${ }^{23}$
22. KOVIC. Born on the Fourth of July, p. 161.
23. KOVIC. Born on the Fourth of July, p. 165. 
24. CARUTH. Confronting Political Trauma, p. 179.
However, Kovic's statement shows that the homecoming of Vietnam veterans critically involves the debate of trauma studies. In general, the study of trauma focuses in large part on the bodily or psychic mechanisms through which trauma is experienced and remembered, and more specifically, on the extent to which trauma can be considered a discursive or extra-discursive event, registered either in consciousness or directly in the body. Nevertheless, in her article "Confronting Political Trauma", Caruth explains that:

To listen to the soldiers' voices and to see through their eyes is no simple task; however, the truth to which they have asked us to listen concerns both the horror of war-or, in particular, the horror of a war that has not been clearly justified-and also the horror of betrayal, the betrayal of the public and of the soldiers themselves by a government not willing to reveal either its own motives for entering and escalating the war, or its intentions for remaining there in a stalemate. ${ }^{24}$

The post-war has revealed that the traumatic symptoms of Vietnam veterans helped to assert the vets' identity as the vets' being the "horror of war." The vets' narratives produced after the Vietnam War are often based in a mix of images, memories and sufferings that usually keep haunting the vets and shocking their minds to establish the horror. Thus, harmful psychological effects from unpleasant traumatic experiences have being established as the main characteristics of the vets' narratives in the post war period.

In Paco's Story, Larry Heinemann writes about the difficulties and struggles of the wounded soldier's return home from the Vietnam War, Paco Sullivan, who has a hard time in finding a place to live and work in the U.S. Even though, Paco "wants to discover a livable peace" ${ }^{25}$, but things don't really happened the way he expected. Paco returns to the United States with his legs full of pins, badly scarred and limping. He needs daily rations of Librium and Valium and cannot figure out what to do next. According to Heinemann,

" Paco would sit up in bed, sore and exhausted, gazing down at himself - bitterly confronted with that mosaic of scars - waiting for his nightly doses of Librium and Valium to overwhelm him" ${ }^{26}$. Yet, he becomes an introspective dishwasher in the small town of Boone, no matter how hard he works, nothing muffles the anguish in his mind and body and "sometimes he prances around, but kind of hobbling, kind of deeply and slowly limping. He's got the pills and that bottle on the dresser. Getting more and more drunk, holding his head with both hands" ${ }^{27}$. Returning home was not an easy task at all for the American veterans who fought the Vietnam War. The vets were contaminated and alienated by the Vietnam War and often seen as someone who has never belonged to America. They were the unwanted Americans, wronged and helpless.
25. HEINEMANN. Paco's Story, p. 174.

26. HEINEMANN. Paco's Story, p. 136.
EM TESE

v. 20

N. 2

MAIO-AGO. 2014

ARAÚJO. The homecoming experience: the enemy never dies

P. $208-229$ 
28. HEINEMANN. Paco's Story, p. 206-207.

29. HEINEMANN. Paco's Story, p. 101.
In Paco's Story, Heinemann uses the metaphor of a ghost to illustrate how the other characters in the novel see the strangeness of Paco. Cathy, for instance, remarks in her diary how her aunt Myrna sees Paco: "aunt Myrna says he has a way of stiffening up and staring right through you. As if he's a ghost. Or you're the ghost". Paco was indifferent to the world around him and he carried on living like that, "clean, dirty, it's all the same to him". Yet, he looks "like death warmed over. Like he was someone back from the dead" 28 Paco however, with his body full of scars, looks more like a living "map" of the Vietnam War in America. He is described as a kind of "braille" or a "mosaic" to be read, appreciated, and someone that awakens curiosity "as if each scar had its own story” ${ }^{29}$. Thus, Vietnam Veterans like Paco became a kind of unique personality in the American society. If in one hand the veterans arouse some curiosity, in which just few Americans tried to understand who the vets really were on the other hand, most of the American people ignored such strange figures among them. The vets' accounts usually show that many civilians were afraid and scared of so many mutilated and deformed soldiers who, in turn collaborated to depreciate the image of their communities.

Although the Vietnam War was over, the tragic consequences of it lasted for many years. The veterans had returned home, but the national warm welcome back never really happened. Neil explains that, "the returning veterans were treated casually by others in the community as if they were away on vacation". ${ }^{30}$ When Kovic and his veteran friend Eddie arrived in the United States from the Vietnam War they were invited to join a small Memorial Day parade in their hometown. Kovic then begins to feel that there was something different going on inside of him and also on the crowd's reaction. He realized that the sense of the meaning he had about the war was not the same. Kovic and Eddie went up to the stage parade to greet the public, but people were careless. "The parade had hardly begun but already he felt trapped, just like in the hospital" ${ }^{31}$, and instead of people waving and cheering, the crowd stood, "staring at Eddie Dugan and himself like they weren't even there. . . . And he couldn't understand what was happening" ${ }^{32}$. Later on, the "tall commander," a veteran of World War II, faces the crowd and, "almost crying now, he shouted to the crowd that they couldn't give up in Vietnam. 'We have to win...' he said, his voice still shaking; then pausing he pointed his finger at him and Eddie Dugan, "because of them!" ${ }^{33}$. Kovic got confused with the crowd's attitude and he was wondering "why he and Eddie hadn't even been given the chance to speak" ${ }^{34}$. Kovic explains that "He was beginning to feel very lonely. He kept looking over at Eddie. Why hadn't they waved, he thought. Eddie had lost both of his legs and he had come home with almost no body left, and no one seemed to care" ${ }^{35}$. Kovic then realized that part of the American society
30. NEIL. National Trauma and Collective Memory: extraordinary events in the American experience, p. 101.

31. KOVIC. Born on the Fourth of July, p. 108.

32. KOVIC. Born on the Fourth of July, p. 90.

33. KOVIC. Born on the Fourth of July, p. 92-93.

34. KOVIC. Born on the Fourth of July, p. 93.

35. KOVIC. Born on the Fourth of July, p. 105.
EM TESE
BELO HORIZONTE
v. 20
N. 2
MAIO-AGO. 2014
ARAÚJO. The homecoming experience: the enemy never dies
P. $208-229$ 
36. APPY. Working-class war: American combat soldiers and Vietnam, p. 321

could not forget that the United States lost the war. The discussions about the role and importance of America in the war were still relevant in some communities, and for some American citizens they should have never gone to fight the war in Vietnam. Moreover, Appy explains that,

Most public discourse about veterans suggested that their problems were primarily ones of readjustment, that veterans returning individually from war lacked collective reentry rituals, that they reentered civilian society so rapidly they did not have enough time to "decompress," and that society failed to offer veterans the gratitude and welcome so necessary to the reestablishment of a positive civilian identity. While those matters are not unimportant, the simplistic implication of much commentary about veterans was that everything would have been fine had these men simply been given a parade, a pat on the back, and a few more benefits. However, to follow Peter Marin's argument once again, society has not yet adequately addressed "the unacknowledged source of much of the vets' pain and anger: profound moral distress, arising from the realization that one has committed acts with real and terrible consequences. ${ }^{36}$

For many other Americans, as a result, the act of wanting to forget the war involved their wish to forget the misery, the death and the atrocities they had followed for many years in the press and television news broadcasts. As Michael Clark has noted:

Since the withdrawal of American troops from Vietnam in 1975, the media industry in the United Sates has worked doggedly to represent that war and its veterans in a form compatible with the traditional norms of popular culture, and the various events surrounding the tenth anniversary of the fall of Saigon testified to the complete success of that program. New memorials were dedicated, complaints about Agent Orange ${ }^{37}$ paid off, and lingering problems with unemployment, crime and the emotional complexities of Post-Vietnam Syndrome were dismissed as the adolescent whining of chronic malcontents by upwardly mobile veterans whose happy families and fine jobs proved that the Vietnam Vet was really OK. ${ }^{38}$

A new image and history of the war was created to relieve and comfort American citizens, but for the vets this attempt in trying to overcome the cataclysm of Vietnam is something that only collaborated to increase the lies and disgrace the vets were already used to. It was very difficult for the Vietnam veterans to accept a new approach attempting to represent the war they were still fighting in their minds, especially when such an approach was coming from the press, the media, or the government that had betrayed them. Vietnam was still vivid in their minds, bodies and souls. Many veterans had the feeling that they were still fighting a war, rather than truly being at home and there was nothing they could do to forget it. Kovic's experiences shows that denying the truth of what he had lived through in Vietnam was impossible:
37. Agent Orange: a poisonous chemical used by US soldiers during the Vietnam War to remove the leaves from forests so that they could see the enemy. It caused birth defects in many Vietnamese children, and after the war about 60.000 former US soldiers complained of illnesses.

38. CLARK. Remembering Vietnam, p. 46.
EM TESE

BELO HORIZONTE

v. 20

N. 2

MAIO-AGO. 2014

ARAÚJO. The homecoming experience: the enemy never dies

P. $208-229$ 
39. KOVIC. Born on the Fourth of July, p. 127.

40. HARIMAN. Critical Studies in Media Communication, p. 40

41. HEINEMANN. Paco's Story, p. 136. every morning I wheel into the bathroom of my new apartment and throw up. It frightens me to live alone with my paralyzed body and my thoughts of Vietnam. I'm dreaming too often of the dead corporal. The tension and fear are twisted up inside me like a loaded spring. ${ }^{39}$

Kovic's traumatic memories followed him insistently, disturbing and harming his life. His constant feeling of desperation is something which many veterans would identify with Kovic's pain, "like all great pain, disrupts and breaks up the social world's pattern of assurances" ${ }^{40}$. In a similar way, Paco's great psychological and physical pain also disrupts the patterns and values that American society is used to. Although the vets were in a rich country that could offer comfort, good treatment, and financial assistance, most of the vets had difficulties in attaining such privileges due to the real difficulties and struggles during their transitions back home. The veterans faced redeployment back to overseas duty, and their communities were not prepared to reintroduce them back home. The war trauma was alive, vivid and continuing to shock and harm the veterans' minds and bodies. The trauma seemed to spread among the veterans like an epidemic. Paco, for instance, "luxuriating in the stupefying doses of Librium and Valium" was constantly recalling the fascination lived on the battlefield. ${ }^{41}$ He needs to take daily doses of drugs to keep going, and no matter how hard he works or how long ago the war was over there was nothing he could do to ease the mental suffering he constantly experiences. The traumatic memories of the war keep invading his mind like a ghost which he cannot escape. Thoughts and nightmares about cataclysmic Vietcong attacks are constant threats that overwhelm him. Everyday there is something that brings back savage memories. As describes some of his nights:

I still dream about it nights - nightmare monsters that smell to high heaven, nasty whirligig-looking contraptions that keep snatching at you, slobbery-looking warlocks with the evil fucking' eye that gives you cold sweats and shivers so bad you think you got some dynamite dose of malaria. ${ }^{42}$

Back home Paco is often imprisoned at nights in his own bedroom and his nightmares seem to last forever. The war zone exposure is a life change experience and it has changed Paco's life utterly and forever, incapacitating him to live a normal life. Paco explains that his memories were usually about,

guys with their heads cracked open like walnuts, bleeding from their ears and the scalp. Guys with their chests squashed flat from fucking'-A booby-trapped bombs. Guys with their legs blown off at the thighs, and shrapnel hits from there on up from a direct hit with a Chicom RPG - an armor-piercing rocket-propelled grenade. ${ }^{43}$
42. HEINEMANN. Paco's Story, p. 21.

43. HEINEMANN. Paco's Story, p. 20-21. 
44. APPY. Working-class war: American combat soldiers and Vietnam, p. 310.

45. HENDIN. Wounds of War, p. 8889.
He is constantly threatened by traumatic memories that create continuous conflicts in his mind. The representation of Paco's experiences shows the resemblance between Paco, Kovic and the other Vietnam veterans, reaffirming their war experiences as an intense struggle against the symptoms generated by the war. Nevertheless, Appy asserts that, "more than 500,000 Vietnam veterans who suffered some form of posttraumatic stress syndrome did not experience the worst symptoms until five or even ten years after their tours" ${ }^{44}$. These traumatic memories of Vietnam War became part of the vets' daily routine, changing their lives intensively and making their lives something impossible to be recovered. An irreconcilable change happened in the vet's minds, and they had to deal with the impossibility of having their friends, families and nation as the ones who would support them in the process of healing the traumas of war. According to Herbert Hendin,

This response to combat trauma involves eternal vigilance in dealings with others, an expectation that any argument is a prelude to a violent fight.... Under such emotional pressure, the veteran perceives civilian life as an extension of the war and almost everyone... is seen as a potential enemy.... [They have] a perpetual readiness for attack, even when no danger exists. ${ }^{4}$

Loneliness and despair are the vets' most common characteristics narrated in their novels and accounts. Pretty much everything related to the veterans or the Vietnam War was not considered as being good for America. Without any support back home, the veterans felt abandoned, and they did not find a way to share what was happening in their inner side. Intensive feelings of sadness, nightmares, and a sense of numbness were the most visible traumatic consequences. They were abandoned, and responsible for taking care of themselves. Appy explains that,

Even the Veterans' Administration, an agency that for ten years refused even to acknowledge the existence of psychological problems specifically related to service in Vietnam, eventually conceded that at least 500,000 veterans suffered from Vietnam Delayed Stress Syndrome or, as it is now most commonly known, post-traumatic stress disorder. Specialists who treat this disorder usually place the figure a good deal higher, at about 800,000 , and extensive interviews with veterans suggest that for every man who might be clinically diagnosed with the syndrome, there are just as many who share a number of its symptoms or suffer a milder form. Furthermore, among the many veterans who have lived stable and productive civilian lives, a considerable number have indeed denied or repressed their war-related pain or attributed it to some other, more manageable source. ${ }^{46}$

Back home there was no government to rely on or family to understand the veterans' pain. Nobody would trust the vets anymore; they were called cowards, and they were the
46. APPY. Working-class war: American combat soldiers and Vietnam, p. 320
EM TESE

BELO HORIZONTE

v. 20

N. 2

MAIO-AGO. 2014 
47. NEIL. National Trauma and Collective Memory: extraordinary events in the American experience, p. 101. ones responsible for smearing the image of American history. A bitter defeat became part of the Vietnam veterans lives, echoing in their hearts and minds the shame and guilty of losing the war. They were the first to lose an American War, and now would have to carry this traumatic burden for the rest of their lives. Neil states that:

Psychologically, the veterans were still fighting the Vietcong and dodging land mines. The Veterans were also victimized by returning home to face such negative stereotype as "ruthless baby-killer", "drug addict", and "having fought in an immora war." There was a lack of appreciation both by the general public and the American government. The nation wanted to put the trauma of the war behind and get on with the business of restoring normality. ${ }^{47}$

The vets had to struggle psychically and physically to survive, and finding a job became part of their struggle. They had a problem in being accepted as honest and good workers. Civilians and the government avoided the veterans due to their lack of experience, and because they were very young, many of them had never worked before. They had their first job in the army and many of them only knew how to kill. And because they lost the war, people also thought that they could not work well, and no one wanted to work with a "drug addict" or a "baby killer". According to Neil, "a former helicopter pilot was requested to take off his coat so a potential employer could see if there was evidence of needle marks for taking drugs; a nurse who had served in a medical combat unit in Vietnam was assigned to emptying bedpans in a civilian hospital". ${ }^{48}$ The veterans hardly ever received support from the government, and most of them did not have the chance to be introduced into society again. Thus, to work and start life normally was almost impossible. Neil explains that

many veterans developed sleep disturbances, such as difficulty in getting to sleep, waking too early in the morning, or sleeping too much. Sleep was frequently disrupted by recurrent nightmares in which the veteran saw themselves dodging land mines and booby traps, encountering ambushes, watching their buddies die, or witnessing or participating in atrocities. Thus, the war did not end for many of the veterans with their return to civilian life. The problems remained of reconstructing their experiences and their self- identities. ${ }^{49}$

Kovic's sleeping experience was full of problems and worries. As he complains: "Sometimes I'd have terrible nightmares about the war. I'd wake up scared in my room in the middle of the night. There was no one to hold on to, just myself there inside my frozen body" ${ }^{50}$. In addition to the nightmares and loneliness, Paco does not always have a place to stay:

He grins hard against the still-emerging, burgeoning pain rising from under the fading medication; he thinks, I have two
48. NEIL. National Trauma and Collective Memory: extraordinary events in the American

49. NEIL. National Trauma and Collective Memory: extraordinary events in the American experience, p. 102.

50. KOVIC. Born on the Fourth of July, p. 163.
EM TESE v. 20
MAIO-AGO. 2014
ARAÚJO. The homecoming experience: the enemy never dies P. 208-229 
51. HEINEMANN. Paco's Story, p. 66.

52. APPY. Working-class war: American combat soldiers and Vietnam, p. 297. things to do before dark, find work and get a place to stay; any damn work, bear even chintzy damn day labor, and a place to sleep, but not a flop. I'm through with flops; through with sleeping outdoors wrapped in every shirt I own, be goddamned sure of that; through with musty, itchy barn lofts, hospitals (when they let you sleep), and shit-for-nothing, bunkhouse hostels saturated with cockroach poison. ${ }^{51}$

Paco, Kovic and many other veterans had a hard time to reconstruct their lives according to the patterns of the American society, and their traumas were almost always preventing them from being sociable again. If there was a process that vets could go through to try to restore their self-identity it would demand a lot of time, patience and an understanding that vets and civilians could not bear with yet. The fact that many Vietnam veterans were poor and uneducated helped to increase their problems and also to slow the process of introducing them back to society. According to Appy,

American soldiers found in Vietnam a painful and confusing mirror in which to reflect upon their place in American society. "Poor" in one society, they were "rich" (but "cheap") in another. They were caught in the middle of a struggle between the First World and the Third, a struggle that left thousand of veterans feeling utterly adrift, like homeless and abandoned executors of American power. ${ }^{52}$
In an interview with the psychiatrist Robert Jay Lifton, Caruth discusses some of the features regarding trauma and identity. Lifton explains that trauma can also be thought as a theory of the self. He understands that extreme trauma creates a second self which is radically altered, but despite trauma being extreme, trauma correlates to the person's identity. Thus, a traumatized self is created, although, this self is not totally a new self. According to Lifton, this apparently new self is "what one brought into the trauma as affected significantly and painfully, confusedly, but in a very primal way, by that trauma. And recovery from post-traumatic effects, or from survivor conflicts, cannot really occur until that traumatized self is reintegrated" ${ }^{53}$.

The war trauma lived by Vietnam vets back home intensified their suffering as a constant threat and gave the veterans a new post-war identity that reaffirmed who the vets really were. They often found trouble in asserting their identity. It was difficult for them to have an aim or a focus for their lives and many of them never really understood what to achieve in their post-war life. Kovic, however, found out that protesting against the war would help him to give meaning to his life. Through the years after the war, he understood pretty well what matters were involved in the Vietnam War, the lies, the corruption and the political interests that lay behind it. Besides, he could use his own disgrace to favor him in this new stage of his life:
53. CARUTH. Trauma: Explorations in Memory, p. 137. 
54. KOVIC. Born on the Fourth of July, p. 150.
This body I had trained so hard to be strong and quick, this body I now dragged around with me like an empty corpse was to mean much more than I had ever realized. Much more than I'd known the night I cried into my pillow in Massapequa because my youth had been desecrated, my physical humanity defiled. I think I honestly believe that if only I could speak out to enough people I could stop the war myself. I honestly believe people would listen to me because of who I was, a wounded American veteran. ${ }^{54}$

Kovic then started to feel useful again, a new strength took over his body and gave him a new task in life, protesting against those who were promoting the war. Many veterans' reports claim that in Vietnam they were completely different people, during their service in the Vietnam War and especially in the battlefield, they took on a new identity. They were trained to forget all the values they had acquired at home with their families, friends, and teachers. At the war, the vets had to incorporate the new self they were trained for. They became machines to kill and destroy. But back home, the veterans with their contaminated identity were useless and they suffered the consequences of the war when it was finally over.

Since many veterans had difficulties in forgetting their unwanted memories, some of them even tried to move to a different country as way to escape from people and things that would remind them of the war. It was very hard for veterans to openly share their war experiences with others, and even if they met other Americans or other veterans, there was a psychological distance that would often set them apart from the normal social environment. Their conversations were full of pain and frustration. Many relatives and former friends did not know how to interact with them or deal with their reality. The civilians were not able to manage this process of accepting the vets back home because they were not prepared or trained for this. The veterans were psychologically isolated with no support to rely on, and the reconstruction of their identity was something hard to achieve. According to Neil:

The post-traumatic stress syndrome included persistent feelings of sadness or emptiness, an inability to drive pleasure from everyday activities, difficulty in concentrating or making decisions, feelings of guilt and pains that did not respond to treatment. The war veterans were disproportionately represented among alcoholics, hospital patients, the divorced, and

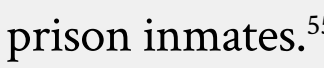

Many of the veterans returning from Vietnam lost the sense of relationship, and they did not know how to relate to their families and friends in the same way they used to do before the war. The vets also had many problems with
55. NEIL. National Trauma and Collective Memory: extraordinary 
56. NEIL. National Trauma and Collective Memory: extraordinary events in the American experience, p. 103. sustaining a more intimate relationship with members from the opposite sex. They did not know how to offer and find assistance for their loved ones. During the war the army somehow taught them to be emotionless about things related to women, so they could entirely focus their strength, thoughts and emotions on the enemy. They had to find a way to manage their feelings and leave their emotions for women alone. Neil explains that, "emotionality was seen as a feminine characteristic that had no place in the macho world of the military. As one platoon sergeant put it, 'Sentiment is a word in the dictionary somewhere between shit and suicide" ${ }^{56}$. The soldiers were trained not to show emotions or express sorrow for whatever happens in Vietnam. However the way Paco was assaulted at Fire Base Harriette during his tour in Vietnam clearly illustrates how willing the American veterans were to accomplish the task they were given, even if it was necessary to attack their own American platoon:

But most particularly, people think that folks do not want to hear about the night at Fire Base Harriette - down the way from LZ Skator-Gator, and within earshot of a ragtag bunch of mud-and-thatch hooches everyone called Gookville - when the whole company, except for one guy, got killed. Fucked up dead, James; scarfed up. Everybody but Paco got nominated and voted into the Hall of Fame in one fell swoop. The company was night-laagered in a tight-assed perimeter up past our eyeballs in a no-shit firefight with a battalion of headhunter NVA - corpses and cartridge brass and oily magazines and duc frags scattered around, and everyone running low on ammo. Lieutenant Stennett crouched over his radio hoarsely screaming map coordinates to every piece of artillery, every air strike and gunship within radio range, like it was going out of style, when all of sudden - zoom - the air came alive and crawled and yammered and whizzed and hummed with the roar and buzz of a thousand incoming rounds. It was hard to see for all the gun power smoke and dust kicked up by all the muzzle flashes, but everyone looked up - GIs and zips - and knew it was every incoming round left in Creation, a wild and bloody shitstorm, a ball-busting cataclysm. ${ }^{57}$

At Fire Base Harriette the sudden attack happened without any remorse. This attack shows that American soldiers were ready to use their gun power without thinking about the results of its destruction. The passage demonstrates that in Vietnam an American soldier could act emotionless and indifferent. Luckily, Paco was the only survival of such a cataclysm, but the physical and emotional pain of the wounds inherited in this attack will follow him forever.

Once the vets had no feelings left anymore they could keep a low expectation or no understanding at all in terms of seeing the war as something evil or unnecessary. By being emotionless, they could also protect themselves from the

\begin{tabular}{|c|c|}
\hline BELO HORI? & \\
\hline
\end{tabular}


effects of the war to be immune from the atrocities faced in their everyday war routine. However, back home things were completely different, and all the emotions that were repressed in the war came to the fore. The vets wanted and felt the need to have a relationship. They wanted to be with the opposite sex. They wanted to experiment the sexual relation that the battlefield was not able to offer. Many of them kept wondering where and what kind of women would have a relationship with a deformed veteran. After the war, many of the vets had their bodies mutilated or severely wounded and some of them could not have sex anymore, like Kovic. With their bodies often full of scars and pain, the vets believed they were monstrously unattractive to women. Traumatized, they were not capable of fulfilling sexual relationships. However, they dreamed about having sex, and they patiently waited for an opportunity to be sexually redeemed. Heinemann shows that,

fucking the girl is something Paco has dreamed about over and over, sprawled spread-eagle on his creaking bed, with his flaccid cock (slashed with scars) flopped to one side of his thighs - oh, how his back would ache on those nights - his pubic hair fluffy and prickly, almost cracking in the heat, like dry grass. ${ }^{58}$

Paco wishes to have sex with his next door neighbor Cathy. It becomes an obsession and a routinely characteristic in his thoughts and imagination. For most veterans the subject of sex was not easy to deal with at all. If they really wanted to have sex, many of them had to pay for it. Otherwise, they had to fulfill their sexual need with thoughts, imagination and dreams. For the ones who had already experienced sex before the war, what remained was the pleasant memories of their perfect bodies working in a proper way, without delimitations or any missing part, the way their bodies should have always been. The frustration of not being able to be physically and mentally normal again hurt and agonize the vets. Kovic let his readers aware of his extreme physical and mental pain: "I got paralyzed from the chest down. I can't move or feel anything" ${ }^{59}$. He also shares the agony of having lost all hope in having sex again and how disturbance persists in hurting him:

NONONO, that's not right! That's not fair! I want it back! They have taken it, they have robbed it, my penis will never get hard anymore. I didn't even have time to learn how to enjoy it and now it is gone, it is dead, it is as numb as the rest of me.

I watch other women now. I see their long slim legs standing pretty. I start to get excited, my mind racing with fantasies, and then the hurt comes...

The emotional stress Kovic experienced is common among veterans. He comes home in a wheelchair. His body
59. KOVIC. Born on the Fourth of July, p. 101.

60. KOVIC. Born on the Fourth of July, p. 112.

\begin{tabular}{|c|c|c|c|c|c|c|}
\hline EM TESE & BELO HORIZONTE & v. 20 & N. 2 & MAIO-AGO. 2014 & ARAÚJO. The homecoming experience: the enemy never dies & P. 208-229 \\
\hline
\end{tabular}


61. KOVIC. Born on the Fourth of July, p. 111

62. CARUTH. Trauma: Explorations in Memory, p. 4.

63. APPY. Working-class war: American combat soldiers and Vietnam, p. 72 is shattered by a bullet and he can no longer feel anything below his waist. He is in a very bad situation and desperate to have his strong and healthy body back to the normal. He claims: "I want to feel, I want to feel again. . . . Please God" he says, "I want it back so bad. I will give anything, anything just to be inside a woman again" ${ }^{61}$. Kovic's post-war sexua life experience is a mirror of many other vets' stories whose years of disillusionment and reprimands from their countrymen are added to by the post-war traumatic experiences which they cannot avoid. Caruth explains that, "trauma unsettles and forces us to rethink our notions of experience and of communication" ${ }^{62}$. Hence, Kovic found himself almost incommunicable in his homeland because his traumas were increasing and he could not really understand what had really happened to him. Just like Paco, Kovic had to learn how to live with a deformed body full of scars and pain.

The Vietnam veterans were often afflicted by war trauma. They returned home full of war symptoms and they had to carry this sickness every single day. Appy asserts that, "at a very early age Bob Foley [a Vietnam veteran] learned about alcoholism, divorce, violence, unemployment, loss, and fear: the realities of life. He associated these realities with family life" ${ }^{63}$. Sometimes the vets' family and friends did not know about the vets' symptoms, they did not understand it, and often the vets found themselves unable to share their traumas or did not know how to share them. Thus, the vets' traumas impacted not only their lives, but they also impacted the lives of those who were around them.

In addition, Neil explains that the soldier who survived the war attacks also felt guilty about being alive and they frequently asked questions such as "Why do some men continue to live while others are killed?" and "Why him and not me?" 64 . This survivors' guilt disturbed the veterans and grew out of the chaos of the war. The discussions about what was right or wrong in human affair or who dies and who lives did not always find a reasonable answer, and because of that, for many veterans such fatalities were seen as the will of God.

As years passed by, Kovic understood, through his war experiences, how brutal and sad a war can be, and how the outrageous consequences of war can damage a whole nation. In a letter he wrote to Iraq's and Afghanistan's former soldiers and active-duty service members, Kovic calls for veterans and GIs to support antiwar movements and fight against wars. He came to the following conclusion:

We who have witnessed the obscenity of war and experienced its horror and terrible consequences have an obligation to rise above our pain and sorrow and turn the tragedy of our lives into a triumph. I have come to believe there is nothing in the lives of human beings more terrifying than war and nothing more important than for those of us who have experienced it to share its awful truth. ${ }^{65}$
64. NEIL. National Trauma and Collective Memory: extraordinary events in the American experience, p. 103
EM TESE
BELO HORIZONTE
N. 2 
The Vietnam War narratives, the press, the media and many other reports have shown that the number of Vietnam veterans psychologically disturbed after the war was much bigger than it was during the war. The number of Vietnam veterans who committed suicide back home was much greater than the number of soldiers who died during the war. The Vietnam veterans also had to deal with the embarrassment of being unfavorably compared to men who fought other American wars, especially those of World War II. Many veterans became homeless and their serious emotional problems were never treated properly at the VA hospitals. Many Vietnam veterans have history of alcohol and drug abuse. The unemployment rate and divorce rate for Vietnam vets were much bigger than the national average. And a considerable proportion of all incarcerated people were Vietnam veterans. Thus, the estrangement and difficulties of continuing life after the end of the war, the emotional stress, the prejudice and rejection, became for many veterans their everyday struggle.

In conclusion, the American literature of Vietnam War has shown that the post-war experiences in the life of Kovic, Paco and many other real and literary veterans who fought the Vietnam War, can be seen as the representation of an uttered cry of the vets' despair to show the destructive power of the war. The result of the war in the vets' lives and the way they lost all hope in those who could help them, but instead decided to shrug their shoulders when the vets most needed them can be used as an example for the future American generation. Besides, the Vietnam War brought no answer to America or to the world, but rather disgust and distrust of the American government. And although the U.S. government knows the cost of war, America insists on producing war after war and never considering it as the last option.

The consequences of such actions are the death of soldiers and civilians. The battlefields might have changed and the excuses to fight might be different, but the result of American wars remains the same. Lots of children, women and other civilians are severely victimized. Wars generate horrible memories and traumas that often follow its participants for the rest of their lives. It causes great sorrow and suffering on both sides, with both civilians and veterans heavily feeling the result of such tragedy. The truth, however, is that the American myth of the effectiveness of war persists, the wars continue to happen, and the veterans' experiences have repeated and remained the same, war after war. But as Herman Melville has reminded us: "We are blind to the real sights of this world; deaf to its voice; and dead to its dead" ${ }^{66}$.
66. MELVILLE. 367Red Burn: His First Voyage, p. 367. 


\section{WORKS CITED}

APPY, G. Christian. Working-class war: American combat soldiers and Vietnam.U of North Carolina P, 1993

BAL, Mieke, Jonathan Crewe and Leo Spitzer, eds. Acts of Memory: Cultural Recall in the Present. Hanover: UP of New England, 1999.

BARITZ, Loren. Backfire: A History of How American Culture Led Us into Vietnam and Made Us Fight the Way We Did. New York: W. Morrow, 1985.

Bibby, Michael.Hearts and minds: bodies, poetry, and resistance in the Vietnam era. Rutgers UP, New Brunswick, New Jersey, 1996.

CAPPS, Walter. The Vietnam Reader. Routledge, New York, 1991. CAPUTO, Philip. A Rumor of War.New York: Ballantine, 1978 CARUTH, Cathy. Trauma: Explorations in Memory. Baltimore: The Johns Hopkins UP, 1995

--. Unclaimed Experience: Trauma, Narrative and History. Baltimore: The Johns Hopkins UP, 1996.

--. "Confronting Political Trauma." CT Review Vol. XXVIII No. 1 (Spring 2006): pp. 179-18.

CHAMBERS II, John Whiteclay.The Oxford Companion to American Military History. Ed. John Whiteclay Chambers II. New York: Oxford UP, 1999
CLARK, Michael. "Remembering Vietnam."Cultural Critique, No. 3, American Representations of Vietnam3,1986,p.46-78.JSTOR. Disponívelemhttp://www.jstor.org/stable/135416. Acesso em 15 dez. 2011

EASTLAKE, William. The Bamboo Bed. New York: Simon \& Shuster, 1969

ELLSBERG, Daniel. Papers on the War. New York: Simon and Schuster, 1972.

ERIKSON, E.H. Childhood and Society, Harmondsworth:

Penguin Books, 1965

FITZGERALD, Frances. Fire in the Lake: The Vietnamese and the Americans in Vietnam. Boston: Little, Brown \& Co.,1970.

FRANKLIN, H. B. Mythmaking in America. Lawrence Hill, New York, 1992.

HALBWACHS, Maurice. On collective Memorie, Chicago U P 1992

HANLEY, Lynne.Writing War: Fiction, Gender, and Memory. Amherst: U of Massachusetts P, 1991.

HARIMAN, Robert and John Louis Lucaites. "Public Identity and Collective Memory in U.S. Iconic Photography: The Image of 'Accidental Napalm'." CriticalStudies in Media Communication20.1. Mar.2003. p.35-36. Disponível em http:// www.uni.edu/fabos/seminar/readings/Harriman2.pdf Acesso em 01 jul. 2014. 
HENDIN, Herbert, and Ann Pollinger Haas. Wounds of War. New York: Basic Books, 1984

HEINEMANN, Larry. Paco's Story. Faber and Faber, London, 1989 HERMAN, Judith. Trauma and Recovery.New York: Basic Books, 1992

HERR, Michael. Dispatches. New York: Avon Books, 1980

HERZOG, Tobey C. Vietnam War Stories: Innocence Lost Routledge, New York, NY, 1992

JEFFORDS S., TheRemasculinization of America: Gender and The Vietnam War, Indiana U P, Bloomington, 1989.

KOTARBA, J. A. Chronic Pain: Its Social Dimensions, Beverly Hills: Sage, 1983

KOVIC, Ron. Born on the Fourth of July. New York: Pocket Books, 1976.

--. "Raise your voices, protest, stop these wars." MarchForward 09 Dez. 2010.Disponível em http://www.stopthesewars

org/2010/12/10/ron-kovic-\%E2\%80\%98raise-your-voices-proteststop-these-wars\%E2\%80\%99/. Acessoem16 Nov. 2011.

LEWIS, Michael. Shame: The Exposed Self. New York: The Free Press, 1992

LIFTON, Robert Jay. Home From the War, New York: Pocket Books, 1976
LINDY, Jacob. Vietnam: A Casebook. New York: Brunner/Mazel, 1988 .

LOMPERIS, Timothy J. "Reading the Wind" The Literature of the Vietnam War. Durham: Duke UP, 1987.

LUCKHURST, Roger. The Trauma Question.New York: Routledge 2008

LYONS, Paul. "Toward a Revised Story of the Homecoming of Vietnam Veterans."Peace \&Change, abr. 1998. Disponível em http://loki.stockton.edu/ lyonsp/graphics/toward_a revised.pdf. Acessoem 01 de jul. 2014

MELVILLE, Herman. Red Burn: His First Voyage. New York: Harper \& Brothers, Publishers, 82 Cliff Street. 1850.

NEIL. Arthur G. "National Trauma and Collective Memory: extraordinary events in the American experience."M.E. Sharpe, New York, 2005.

O'NAN, Steward. The Vietnam Reader. New York: Anchor, 1998. O'BRIEN, T. If I Die In a Combat Zone: Box Me Up and Ship Me Home. Delacorte Press, 1973.

SCHULZINGER, Robert D. A Time for War: The United States and Vietnam, 1941-1975. New York: Oxford University Press, 1997.

SEARLE, Willian J. Search and Clear:Critical Responses to Selected Literature and Films of the Vietnam War. Bowling Green State UP, 1998 
SEVY, Grace. The American Experience in Vietnam: a reader. U

of Oklahoma P, Norman, 1899.

TAL, Kali. Worlds of Hurt: Reading the Literature of Trauma. Cambridge U P, 1996

WALSH, Jeffrey. American War Literature:1914 to Vietnam. St. Martin's Press, 1982.

WHITE, Hayden. "The Historical Text as Literary Artifact."Ed.

Adams \& Leroy Searle, eds. Critical Theory since 1965.

Tallahassee: UP of Florida, 1986.

Young, Marilyn Blatt. The Vietnam Wars 1945-1990. New York Harper Collins Publishers, 1991 